fed ad libitum until slaughter at $2 \mathrm{~kg}$ live weight, as either pellets, mash (6o p. Ioo meal, $4^{\circ} \mathrm{p}$. Ioo water) or meal in a $2 \times 3$ factorial design with 4 replicates.

Daily liveweight gain (DLG) over a 6 week period for $8 \mathrm{M} / \mathrm{D}$ mash and meal diets were 0.264 and $-6.218 \mathrm{~g} \mathrm{DLG}$ on $8 \mathrm{M} / \mathrm{D}$ pellets was $20.73 \mathrm{~g}$, and was significantly lower $(\mathrm{P}<0.0 \mathrm{I})$ than on any of the I $2 \mathrm{M} / \mathrm{D}$ treatments. DLG for diets $\mathrm{I} 2 \mathrm{M} / \mathrm{D}$ pellets, mash and meal were 33. $10,27.90$ and $26.5 \mathrm{I}$ g, respectively (SED $\leftarrow 2.32 \mathrm{I} \mathrm{g}$ ); the pelleted diet gave significantly higher DLG than meal $(\mathbf{P}<0.05)$. Mean total DM consumptions of $8 \mathrm{M} / \mathrm{D}$ pellets, $12 \mathrm{M} / \mathrm{D}$ pellets, mash and meal were $4.688, \mathrm{r} .985, \mathrm{I} .94 \mathrm{I}$ and $2.552 \mathrm{~kg}$ (SED $\pm 0.6 \mathrm{I} 4$ ), respectively. Differences were significant $(\mathrm{P}<\mathrm{o.00I})$ between $8 \mathrm{M} / \mathrm{D}$ and $\mathrm{I} 2 \mathrm{M} / \mathrm{D}$ diets.

Killing-out percentages (KO p. IOo) were $57.53,59.08,61.02$ and 63.14 or $8 \mathrm{M} / \mathrm{D}$ pellets, $\mathrm{I} 2 \mathrm{M} / \mathrm{D}$ pellets, mash and meal diets, respectively $(\mathrm{SE} D \pm 2.92)$. The $\mathrm{I} 2 \mathrm{M} / \mathrm{D}$ meal diet gave significantly $(\mathrm{P}<0.05)$ higher $\mathrm{KO} \mathrm{p}$. Ioo than the pelleted diets, while gut contents were significantly $(\mathrm{P}<\mathrm{o}$.or $)$ heavier from the $8 \mathrm{M} / \mathrm{D}$ diet.

$8 \mathrm{M} / \mathrm{D}$ mash and meal diets are clearly unsuitable for growing tabbits. The results show that both metabolisable energy concentration and form (particularly with low energy diets) are important in determining food consumption and therefore growth rate and certain carcass characteristics.

\title{
Effect of food restriction on growth performances and visceral measurements in young rabbits between 5 and 8 weeks of age
}

\author{
F. I,EBAS, J. P. I,APLACE \\ Laboratoive de Recherches sur l'Élevage du Lapin, I.N.R.A., \\ B.P. I2 - 31з2o Castanet Tolosan (France) \\ Laboratoive de Physiologie de la Nutrition, I.N.R.A. C.N.R.Z., \\ 78350 Jouy-en-Josas (France)
}

Fourty-eight Californian rabbits of both sexes, aged 5 weeks, were distributed into 4 groups corresponding to 4 techniques of administration of the same pelleted diet.

A group: ad libitum feeding every day.

$B$ group: Free access to pellets only during 5 days a week, i.e. Tuesday, Wednesday, Friday, Saturday and Sunday.

$C$ group: Daily administration of a limited quantity of pellets corresponding to $7 \mathrm{I}$ p. $100(=5 / 7)$ of the ad libitum feeding of an preexperimental group.

$D$ group: Every week, supply of the same quantity of pellets as in group C, but only two times a week on Tuesday $(3 / 7)$ and Friday $(4 / 7)$.

The animals were slaughtered at 8 weeks of age and visceral measurements were made.

Daily food intake during $2 \mathrm{I}$ days was similar for the 3 restricted groups $(B, C, D)$ and the mean, 2 I $\mathrm{p}$. I oo lower than for group A. As compared with group A, the daily live weight gain of group C was reduced by $27 \mathrm{p}$. I 00 , that of groups B and D by $48 \mathrm{p}$. Ioo. Considering the daily carcass weight gain, the reduction was similar for the 3 restricted groups (22 to 29 p. Ioo). Stomach and small bowel weight were not affected by any type of restriction. Caecum was heavier for group $\mathrm{C}$, but colon weight was reduced by $15 \mathrm{p}$. 1 oo for groups B and D. The content of viscera was enhanced for the stomach in groups $C$ and $D$ and for caecum in all restricted groups $(+4 \mathrm{I}$ to $+44 \mathrm{p}$. Ioo). The liver weight was quite the same for groups $\mathrm{A}, \mathrm{B}$ and $\mathrm{D}$, reduced by $27 \mathrm{p}$. I oo for group $\mathrm{C}$. 